\title{
Gambaran Kesehatan Mental (Cemas dan Depresi) Pada Masyarakat Di Masa Pandemi CoVID-19: Literature Review
}

\author{
M. Arif Aulia Kusuma ${ }^{1 *}$, Nur Izzah ${ }^{2}$ \\ 1,2 Program Studi Sarjana Keperawatan, Universitas Muhammadiyah Pekajangan Pekalongan, \\ Indonesia \\ *email: arifaulia78@yahoo.com
}

\begin{abstract}
Mental health is one of the essential aspects of maintaining good physical health. The COVID-19 pandemic causes the undertain condition, serious illness, misinformation and social isolation, which are the main things that contribute to stress and mental disorders. To picture mental health in the community during the COVID-19 pandemic. This literature search was used in the PubMed database. Six articles were identified and meet the inclusion and exclusion criteria. The findings were appraised by using the Strobe instrument. There were 2.608 respondents included in this study. This study showed that some respondents experienced anxiety was $(37,8 \%)$, while most respondents did not experience anxiety $(62,2 \%)$. Similarly, most of the respondents were depressed $(40,8 \%)$, and more than half were not depressed $(59,2 \%)$.
\end{abstract}

Keywords: Anxiety, Covid-19, Depression, Mental Health, Society, Pandemic.

\begin{abstract}
Abstraks
Kesehatan mental merupakan salah satu aspek penting dalam mewujudkan kesehatan secara menyeluruh. Pandemi COVID-19 menyebabkan kondisi ketidakpastian, penyakit yang serius, kesalahan informasi dan isolasi sosial merupakan hal-hal utama yang berkontribusi terhadap stres dan gangguan mental. Mengetahui gambaran kesehatan mental pada masyarakat di masa pandemi Covid-19. Penelitian literature review ini dengan mengakses database PubMed didapatkan 6 artikel yang ditelaah sesuai dengan kriteria inklusi, eksklusi serta abstrak. Instrument telaah kritis yang digunakan yaitu menggunakan instrument Strobe yang merupakan analisis metode kuantitatif Cross-Sectional. Hasil penelitian ini didapatkan sebanyak 2.608 responden, Sebagian responden mengalami cemas (37,8\%) dan sebagian besar responden mengalami tidak cemas $(62,2 \%)$. Sebagian responden mengalami depresi $(40,8 \%)$, dan lebih dari setengah responden mengalami tidak depresi $(59,2 \%)$.
\end{abstract}

Kata kunci : Cemas, Covid-19, Depresi, Kesehatan mental, Masyarakat, Pandemi.

\section{Pendahuluan}

Coronavirus disease 2019 atau disebut juga COVID19 ditemukan di Kota Wuhan,China pada tahun 2019. Karena perkembangnya sangat cepat kemudian WHO menyatakan COVID-19 sebagai pandemi global sehingga perlu penerapan pencegahan penyebaran virus Berdasarkan WHO sampai dengan tanggal 30 Mei 2021, total kasus konfirmasi COVID-19 di dunia sejumlah 169.597.415 kasus dengan jumlah kematian 3.530.582 orang. Sedangkan di Indonesia melaporkan jumlah kasus konfirmasi COVID19 sejumlah 1.816 .041 kasus dengan jumlah kematian 50.404 orang dan di Jawa Tengah sendiri ada 199.205 kasus dengan jumlah kematian 7.610 orang dan yang sembuh 186.385 orang [18]. 


\section{Prosiding Seminar Nasional Kesehatan Lembaga Penelitian dan Pengabdian Masyarakat Universitas Muhammadiyah Pekajangan Pekalongan}

Pandemi COVID-19 berdampak di seluruh sektor kehidupan, bukan hanya mengancam kesehatan masyarakat secara fisik, namun dapat memberikan dampak pada kondisi kesehatan jiwa dan psikososial setiap orang salah satunya berdampak pada sektor pendidikan dan perekonomian Indonesia, baik dari sisi investasi, perdagangan, dan pariwisata. Pada sektor pendidikan dampak dari COVID-19 melakukan pembelajaran media daring, COVID-19 juga berdampak di sektor perekonomian pada sisi investasi karena masyarakat akan lebih berhati-hati saat membeli barang maupun berinvestasi Sektor-sektor penunjang pariwisata seperti hotel, restoran maupun pengusaha retail pun juga akan terpengaruh dengan adanya COVID19 Sepinya wisatawan juga berdampak pada restoran atau rumah makan yang sebagian besar konsumennya adalah para wisatawan [15].

$\mathrm{Hal}$ ini sangat mempengaruhi segala aktivitas masyarakat salah satunya penerapan sosial distancing dan physical distancing hingga aturan terkait dengan Pembatasan Sosial Berskala Besar atau PSBB tersebut sehingga dapat mengganggu kesehatan mental emosional seseorang karena ada perubahan dalam keseharian, respon yang muncul bisa bermacam macam mulai dari cemas, depresi, kehilangan pekerjaan, sampai trauma[1].

Sejak wabah COVID-19 melanda Indonesia pada bulan Maret 2020, kegiatan yang mengumpulkan banyak orang dihentikan untuk jangka waktu tertentu. Kegiatan tersebut kemudian dilakukan dirumah atau dikenal dengan Work Form Home (WFH) karena kebijakan yang dikeluarkan oleh Pemerintah Indonesia, banyak orang yang kemudian menghabiskan waktu di dalam rumah. Kegiatan yang sangat lama di rumah tentu menyenangkan bagi sebagian orang namun hal tersebut dapat menyebabkan gangguan kesehatan mental terhadap beberapa orang. Selain kegiatan yang sangat lama dari dalam rumah, wabah ini juga dapat menyebabkan gangguan kesehatan mental [7].

Kesehatan mental merupakan kondisi dimana seseorang dapat berkembang secara fisik, spritual, dan sosial sehingga individu menyadari kemampuan sendiri,dapat mengatasi tekanan, dan mampu memberikan kontribusi untuk komunitasnya Kesehatan mental juga merupakan salah satu aspek yang penting dalam mewujudkan kesehatan yang menyeluruh. Pandemi coronavirus 19 (COVID- 19) menjadikan kesehatan mental yang penting di dunia dan dapat berkembang menjadi masalah kesehatan yang berlangsung lama. Status darurat kesehatan masyarakat yang ditetapkan oleh otoritas kesehatan dunia dengan melakukan pembatasan sosial dan isolasi mandiri atau karantina serta membatasi pergerakan masyarakat akan mempengaruhi kesehatan mental masyarakat[12].

Perhimpunan Dokter Spesialis Kedokteran Jiwa Indonesia (PDSKJI) dalam jurnal (Winurini, 2020) melakukan survei mengenai kesehatan mental melalui swaperiksa yang dilakukan secara daring. Dari pemeriksaan dilakukan terhadap 2.364 responden di 34 provinsi dengan dua masalah psikologis yaitu cemas, dan depresi. Sebanyak 69\% responden mengalami masalah psikologis, 68\% responden mengalami cemas, $67 \%$ responden mengalami depresi dan sebanyak $49 \%$ responden mengalami depresi dan berpikir tentang kematian. Dari data tersebut menggambarkan bahwa kesehatan 


\section{Prosiding Seminar Nasional Kesehatan 2021 Lembaga Penelitian dan Pengabdian Masyarakat Universitas Muhammadiyah Pekajangan Pekalongan}

mental seperti cemas, dan depresi akibat pandemi COVID 19 dirasakan secara nyata oleh masyarakat pada saat itu [19].

Kondisi ketidakpastian, penyakit yang serius, kesalahan informasi dan isolasi sosial merupakan hal-hal utama yang berkontribusi terhadap stres dan gangguan mental. Kondisi ekonomi dan dampaknya juga berpengaruh terhadap kepanikan di populasi umum. Populasi yang berisiko terhadap gangguan kesehatan mental selama pandemi COVID19 diantaranya adalah pasien COVID-19 dan keluarganya, individu yang memiliki komorbid baik dari kesehatan fisik maupun psikologi [8].

Berdasarkan penelitian diatas, maka peneliti tertarik untuk melakukan penelitian tentang "Gambaran Kesehatan Mental (Cemas dan Depresi) Pada Masyarakat Di Masa Pandemi COVID-19: Literature Review'.

\section{Metode}

Penelitian literature review ini dengan mengakses database PubMed dengan rentang waktu tahun 2019-2021 didapatkan 6 artikel yang ditelaah sesuai dengan kriteria inklusi, eksklusi serta abstrak. Kata Kunci yang digunakan Anxiety, Covid-19, Depression, Mental Health, Society, Pandemic. Instrument telaah kritis yang digunakan yaitu menggunakan instrument Strobe yang merupakan analisis metode kuantitatif Cross-Sectional.

\section{Hasil dan Pembahasan} Hasil

Hasil literature review ke-6 artikel tersebut didapatkan responden dengan jumlah 2.608. Berdasarkan Karakteristik masyarakat yang mengalami kecemasan di masa pandemi COVID-19. Hasil analisa dari ke-6 artikel (Shankey Verma,et.al (2020); Ling-Ling Dai, et.al (2020); Yongzhi Zhao ,et.al (2021); Xiao-Bo Zhang,et.al (2021); Btissame Zarrouq et,al. (2021); Rodrigo Antonio de MEDEIROS et.al (2020)) dapat dilihat pada tabel berikut ini:

Tabel 3.1 Hasil Literature Review

\begin{tabular}{|c|c|c|c|c|}
\hline Nama & Judul & Tahun & Negara & Hasil \\
\hline $\begin{array}{l}\text { Shankey } \\
\text { Verma,et.al }\end{array}$ & $\begin{array}{l}\text { Depression, } \\
\text { anxiety,and stres } \\
\text { and } \\
\text { sociodemographic } \\
\text { correlates among } \\
\text { general Indian } \\
\text { public during } \\
\text { COVID-19 }\end{array}$ & 2020 & India & $\begin{array}{l}\text { Hasil penelitian sebanyak } 354 \\
\text { responden. } \\
\text { Berdasarkan kriteria } \\
\text { kesehatan mental } \\
\text { Cemas : } 99 \\
\text { Tidak cemas : } 225 \\
\text { Depresi : } 89 \\
\text { Tidak depresi : } 265\end{array}$ \\
\hline $\begin{array}{l}\text { Ling-Ling Dai, } \\
\text { et.al }\end{array}$ & $\begin{array}{l}\text { Anxiety and } \\
\text { depressive } \\
\text { symptoms among } \\
\text { COVID-19 patients } \\
\text { in Jianghan } \\
\text { Fangcang Shelter } \\
\text { Hospital in Wuhan, } \\
\text { China }\end{array}$ & 2020 & China & $\begin{array}{l}\text { Hasil penelitian didapatkan } \\
\text { sebanyak } 307 \text { responden. } \\
\text { Berdasarkan kriteria } \\
\text { kesehatan mental : } \\
\text { Cemas : } 57 \\
\text { Tidak cemas: } 250 \\
\text { Depresi: } 41 \\
\text { Tidak depresi: } 266\end{array}$ \\
\hline
\end{tabular}




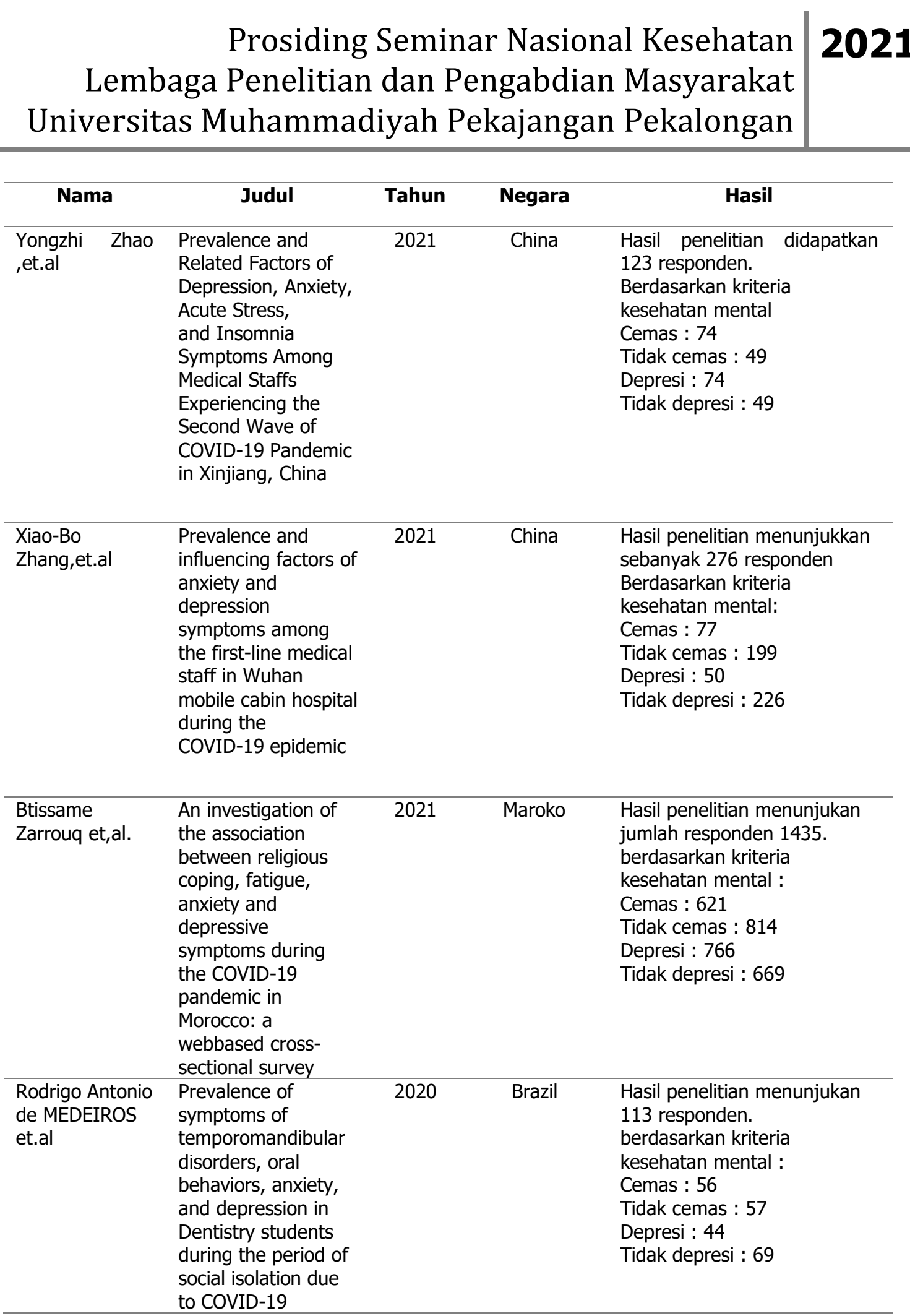

Berdasarkan dari tabel 3.1 didapatkan sebanyak 6 artikel yang di review dengan rentang waktu 2019-2021.

Tabel 3.2 Karakteristik masyarakat yang mengalami kecemasan di masa pandemi COVID-19

\begin{tabular}{ccccccc}
\hline \multirow{2}{*}{$\begin{array}{l}\text { Karakteristik } \\
\text { Masyarakat }\end{array}$} & \multicolumn{3}{c}{ Kategori Kecemasan } & \multicolumn{3}{c}{ Total } \\
\cline { 2 - 5 } & \multicolumn{2}{c}{ Cemas } & \multicolumn{2}{c}{ Tidak Cemas } & & \\
\cline { 2 - 6 } & $\mathrm{N}$ & $\%$ & $\mathrm{n}$ & $\%$ & $\mathrm{n}$ & $\%$ \\
\hline Masyarakat & 720 & 40,2 & 1.069 & 59,8 & 1.789 & 100 \\
Pasien & 57 & 18,6 & 250 & 81,4 & 307 & 100 \\
Staf medis & 151 & 37,9 & 248 & $62,-$ & 399 & 100 \\
Mahasiswa & 56 & 49,6 & 57 & 50,4 & 113 & 100 \\
\hline Jumlah & 984 & - & 1.624 & - & 2.608 & -
\end{tabular}




\section{Prosiding Seminar Nasional Kesehatan $\mathbf{2 0 2 1}$ \\ Lembaga Penelitian dan Pengabdian Masyarakat Universitas Muhammadiyah Pekajangan Pekalongan}

Berdasarkan tabel 3.2 Sebagian mahasiswa mengalami cemas (49,6\%) akibat pandemi COVID-19

Tabel 3.3 Karakteristik Masyarakat yang mengalami depresi di masa pandemi COVID-19

\begin{tabular}{ccccccc}
\hline \multirow{2}{*}{$\begin{array}{c}\text { Karakteristik } \\
\text { Masyarakat }\end{array}$} & \multicolumn{3}{c}{ Kategori Depresi } & \multicolumn{2}{c}{ Total } \\
\cline { 2 - 5 } & \multicolumn{2}{c}{ Depresi } & \multicolumn{2}{c}{ Tidak Depresi } & \\
\cline { 2 - 6 } & $\mathrm{n}$ & $\%$ & $\mathrm{n}$ & $\%$ & $\mathrm{n}$ & $\%$ \\
\hline Masyarakat & 855 & 47,8 & 934 & 52,2 & 1.789 & 100 \\
Pasien & 41 & 13,3 & 266 & 86,7 & 307 & 100 \\
Staf medis & 124 & 31,1 & 275 & 68,9 & 399 & 100 \\
Mahasiswa & 44 & 38,9 & 69 & 61,1 & 113 & 100 \\
\hline Jumlah & 1.064 & - & 1.544 & - & 2.608 & - \\
\hline
\end{tabular}

Berdasarkan tabel 3.3 Sebagian masyarakat mengalami depresi $(47,8 \%)$ akibat COVID-19

Tabel 3.4 Gambaran kecemasan masyarakat di masa pandemi COVID-19

\begin{tabular}{ccc}
\hline Gambaran Kecemasan & $\mathbf{n}$ & $\mathbf{\%}$ \\
\hline Cemas & 984 & 37,8 \\
Tidak Cemas & 1.624 & 62,2 \\
\hline & 2.608 & 100 \\
\hline
\end{tabular}

Berdasarkan tabel 3.4 sebagian responden mengalami cemas $(37,8 \%)$ dan sebagian besar responden mengalami tidak cemas (62,2\%) akibat COVID-19

Tabel 3.5 Gambaran depresi masyarakat di masa pandemi COVID 19

\begin{tabular}{ccc}
\hline Gambaran Depresi & $\mathbf{n}$ & \% \\
\hline Depresi & 1.064 & 40,8 \\
Tidak depresi & 1.544 & 59,2 \\
\hline & 2.608 & 100 \\
\hline
\end{tabular}

Berdasarkan tabel 3.5 sebagian responden mengalami depresi $(40,8 \%)$, dan lebih dari setengah responden mengalami tidak depresi $(59,2 \%)$ akibat COVID-19.

\section{Pembahasan}

Kesehatan mental merupakan aspek penting dalam mewujudkan kesehatan yang menyuluruh. Kesehatan mental juga penting untuk diperhatikan seperti kesehatan fisik. Berdasarkan UU nomor 18 Tahun 2014 tentang kesehatan mental didefinisikan sebagai kondisi dimana seseorang individu dapat berkembang secara fisik, mental, spiritual, dan sosial, sehingga individu menyadari kemampuan sendiri, dapat mengatasi tekanan, dan mampu bekerja secara produktif [2].

COVID-19 tidak hanya memberikan pengaruh pada kesehatan fisik masyarakat saja, kondisi kesehatan mental pada masyarakat selama pandemi juga berpengaruh. 


\section{Prosiding Seminar Nasional Kesehatan Lembaga Penelitian dan Pengabdian Masyarakat Universitas Muhammadiyah Pekajangan Pekalongan}

Kondisi kehidupan masyarakat menjadi berbeda dan banyaknya pemberitaan dan informasi mengenai penyebaran virus COVID-19 yang membuat masyarakat mengalami masalah pada kesehatan mental [14]. Masalah kesehatan mental pada masyarakat di masa pandemi berdasarkan hasil literature review dari telaah ke-6 artikel didapatkan dua masalah psikologis yaitu cemas dan depresi. Dari ke- 6 artikel yang telah di telaah didapatkan sebanyak 2.608 responden

Berdasarkan gambaran kecemasan pada masa pandemi di dapatkan dari telaah 6 artikel didapatkan jumlah 2.608 responden. Sebagian responden mengalami cemas $(37,8 \%)$ dan sebagian besar responden mengalami tidak cemas $(62,2 \%)$. Berdasarkan dari karakteristik masyarakat yang mengalami kecemasan di masa pandemi COVID-19. Sebagian mahasiswa mengalami cemas (49,6\%). Tingkat kecemasan sedang yang dialami oleh mahasiswa dipengaruhi oleh beberapa aspek diantaranya aspek perilaku seperti gelisah, ketegangan fisik, menghindar dan sangat waspada, aspek kognitif seperti perhatian terganggu, konsentrasi memburuk, hambatan berpikir dan takut pada gambaran visual, aspek afektif seperti gelisah, tegang, gugup, ketakutan, kekhawatiran dan kecemasan [11].

Merasakan cemas pada masa pandemi merupakan perasaan yang normal saat menghadapi krisis seperti masa pandemi Covid-19. Kecemasan tersebut akan meningkatkan kewaspadaan seseorang sampai tahap yang wajar agar orang tersebut siap beradaptasi. Namun, bila rasa cemas berlebihan muncul, akan menyebabkan penurunan fungsi dan masalah baru sehingga rasa cemas tersebut perlu dikelola dengan baik [5].

Upaya yang bisa dilakukan untuk mengurangi cemas adalah dengan mengelola kecemasan individu dan keluarga dengan membatasi paparan informasi yang membuat semakin merasa tertekan ataupun cemas. Tidur dengan kualitas yang buruk ditemukan terkait dengan risiko yang lebih tinggi untuk gejala kecemasan, dan kecemasan yang lebih besar ditemukan terkait dengan kualitas tidur yang lebih buruk demikian pula, kecemasan memengaruhi tidur kualitas karena orang cemas sulit untuk tertidur dan sering bangun [3].

Dalam mengelola kecemasan saat pandemi berlangsung dapat dilakukan dengan menggunakan cara-cara mengelola cemas yang pernah dilakukan sebelumnya. Selain itu, langkah lain yang dapat ditempuh adalah mempertahankan gaya hidup sehat. Hal itu bisa dilakukan dengan makan makanan bergizi dan seimbang, istirahat cukup, aktivitas fisik serta olahraga [6].

Berdasarkan gambaran depresi pada masa pandemi didapatkan hasil Sebagian responden mengalami depresi $(40,8 \%)$ dan lebih dari setengah responden mengalami tidak depresi $(59,2 \%)$. Berdasarkan dari karakteristik masyarakat yang mengalami depresi di masa pandemi COVID-19. Sebagian masyarakat mengalami depresi (47,8\%). Gangguan depresi selama pandemi dapat diartikan sebagai emosi yang kuat yang mempengaruhi sesseorang selama pandemi COVID-19 [9].

Banyaknya masyarakat yang mengalami permasalahan kesehatan mental akibat pandemi Covid-19 bisa dipahami mengingat pandemi Covid-19 merupakan sumber depresi baru bagi masyarakat dunia saat ini. Secara global, terdapat empat faktor risiko utama depresi yang muncul akibat pandemi Covid-19 [16]. Yang pertama faktor 


\section{Prosiding Seminar Nasional Kesehatan 2021 Lembaga Penelitian dan Pengabdian Masyarakat Universitas Muhammadiyah Pekajangan Pekalongan}

jarak dan isolasi sosial, yang kedua faktor resesi ekonomi, yang ketiga faktor stress dan trauma dan yang keempat faktor stigma dan diskriminasi.

Upaya yang dapat dilakukan untuk mengatasi depresi antara lain seperti ini mencakup beberapa hal. Hal pertama yang perlu dilakukan adalah membatasi informasi. Prioritaskan untuk mencari sumber berita yang terpercaya, sehingga tidak termakan hoax dan menambah rasa khawatir. Lakukanlah aktivitas yang positif seperti relaksasi, melakukan berbagai hobi yang disukai, berolahraga, memasak, berkebun atau menjadi pegiat kegiatan sosial. Selanjutnya, tetaplah terhubung dengan teman dan saudara, meskipun interaksi fisik dibatasi, tetapi kita masih bisa melakukan sosialisasi dengan berbagai media. Setidaknya kita tidak merasa sendiri dan bisa saling memberikan dukungan sosial [13].

Masalah kesehatan mental pada masyarakat di masa pandemi dapat dikurangi dengan peningkatan pengetahuan tentang pandemi, cara pencegahan dan penularan perlu dilakukan secara terus menerus, tenaga kesehatan melakukan informasi kepada masyarakat. Tenaga kesehatan memiliki peran caregiver yang merupakan peran utama dimana tenaga kesehatan akan terlibat aktif selama 24 jam dalam memberikan asuhan keperawatan pasien, selain itu tenaga kesehatan juga berperan sebagai edukator yang bertugas memberikan pendidikan kesehatan kepada keluarga, masyarakat umum, dan pasien yang sedang mengalami isolasi. Tenaga kesehatan senantiasa berperan dalam peningkatan ilmu pengetahuan dan penyesuaian tatalaksana kebutuhan dasar pasien di masa pandemi. Perjuangan tenaga kesehatan tidaklah bermakna tanpa didukung peran serta aktif masyarakat dalam mengatasi pandemi ini. Keperdulian dan dukungan masyarakat sangat diperlukan dalam penanganan COVID-19 yaitu dengan selalu mematuhi aturan yang dikeluarkan pemerintah dan edukasi yang dikeluarkan oleh organisasi profesi tenaga kesehatan [4].

\section{Kesimpulan}

Pada penelitian literature review kali ini dengan menggunakan 6 artikel yang berbeda didapatkan hasil dari total responden sebanyak 2.608 orang, Sebagian responden mengalami cemas $(37,8 \%)$ dan sebagian besar responden mengalami tidak cemas $(62,2 \%)$. Sebagian responden mengalami depresi $(40,8 \%)$, dan lebih dari setengah responden tidak mengalami depresi $(59,2 \%)$.

\section{Referensi}

[1] Ausrianti, R., \& Andayani, R. P. (2020). Promosi Kesehatan Jiwa Masyarakat Menghadapi Era New Normal. Jurnal Abdimas Saintika, 2(2), 97-101

[2] Ayuningtyas, D., \& Rayhani, M. (2018). Analisis Situasi Kesehatan Mental Pada Masyarakat Di Indonesia Dan Strategi Penanggulangannya. Jurnal IImu Kesehatan Masyarakat, $9(1), 1-10$.

[3] Dai, L. L., Wang, X., Jiang, T. C., Li, P. F., Wang, Y., Wu, S. J., ... \& Cheng, Z. (2020). Anxiety and depressive symptoms among COVID-19 patients in Jianghan Fangcang Shelter Hospital in Wuhan, China. Plos one, 15(8), e0238416. 


\section{Prosiding Seminar Nasional Kesehatan Lembaga Penelitian dan Pengabdian Masyarakat Universitas Muhammadiyah Pekajangan Pekalongan}

[4] F.Jati Wahyu. (2021). Peran Perawat Di Masa Pandemi Covid-19. Retrieved Juli 08,2021, from https://rs.uns.ac.id/peran-perawat-di-masa-pandemi-covid-19/

[5] Hanoatubun, S.(2020). Dampak Covid-19 Terhadap Perekonomian Indonesia.EduPsyCouns: Journal of Education, Psychology and Counseling,2(1), 146-153

[6] Hayulani, Alvinia .(2020). Kecemasan Di Tengah Pandemi COVID-19.Retrived Juni 20, 2021, from https://rsuppersahabatan.co.id/artikel/read/kecemasan-ditengah-pandemi covid-19

[7] Herlina, Neni (2020). Cara Atasi Stres Selama Pandemi COVID-19.Retrived Juni 20,2021, from https://dikti.kemdikbud.go.id/kabar-dikti/kampus-kita/cara-atasistres-selama-pandemi-covid-19/

[8] Innasalma, Anggita.(2020).Menjaga Kesehatan Mental Dalam Masa Pandemi Coronavirus Disease 2019 (Covid-19).Semarang

[9] Levani, Y., Hasanah, U., \& Fatwakiningsih, N. (2021). Stress Dan Kesehatan Mental Di Masa Pandemi COVID-19. PROCEEDING UMSURABAYA.

[10] Maulida, H., Jatimi, A., Heru, M. J. A., Munir, Z., \& Rahman, H. F. (2020). Depresi Pada Komunitas Dalam Menghadapi Pandemi COVID-19: A Systematic Review. Jurnal Sains dan Kesehatan, 2(4), 519-524.

[11] Medeiros, R. A. D., Vieira, D. L., Silva, E. V. F. D., Rezende, L. V. M. D. L., Santos, R. W. D., \& Tabata, L. F. (2020). Prevalence of symptoms of temporomandibular disorders, oral behaviors, anxiety, and depression in Dentistry students during the period of social isolation due to COVID-19. Journal of Applied Oral Science, 28.

[12] Muyasaroh, H. (2020). Kajian Jenis Kecemasan Masyarakat Cilacap Dalam Menghadapi Pandemi Covid 19. LP2M UNUGHA Cilacap, 3.

[13] Ridlo, I. A.(2020). Pandemi Covid-19 Dan Tantangan Kebijakan Kesehatan Mental Di Indonesia. INSAN Jurnal Psikologi dan Kesehatan Mental,5(2), 162-171.

[14] Ridlo, M., Ismail, S., Rochana, N., \& Sarinti, S. Respon Psikologis Perawat Selama Pandemik Covid-19: Scoping Review. Jurnal Ners Indonesia, 11(2), 154-170.

[15] Setyaningrum, W., \& Yanuarita, H. A. (2020). Pengaruh Covid-19 Terhadap Kesehatan Mental Masyarakat Di Kota Malang. JISIP (Jurnal Ilmu Sosial dan Pendidikan), 4(4).

[16] Thakur, V., \& Jain, A. (2020). Covid2019 Suicides: A Globalpsychological Pandemic. Brain,Behavior, And Immunity, No. 88, hal. 952-953

[17] Verma, S., \& Mishra, A. (2020). Depression, anxiety, and stress and sociodemographic correlates among general Indian public during COVID19. International Journal of Social Psychiatry, 66(8), 756-762.

[18] WHO.(2021). Who Coronavirus (Covid-19). Retrieved Mei, 2021, from https://covid19.who.int/ 


\section{Prosiding Seminar Nasional Kesehatan Lembaga Penelitian dan Pengabdian Masyarakat Universitas Muhammadiyah Pekajangan Pekalongan

[19] Winurini, S. (2020). Permasalahan Kesehatan Mental Akibat Pandemi COVID19. Info Singkat, 12(15), 13-18

[20] Zarrouq, B., Abbas, N., El Hilaly, J., El Asri, A., Abbouyi, S., Omari, M., ... \& Ragala, M. E. (2021). An investigation of the association between religious coping, fatigue, anxiety and depressive symptoms during the COVID-19 pandemic in Morocco: a web-based cross-sectional survey. $B M C$ psychiatry, 21(1), 1-13.

[21] Zhang, X. B., Xiao, W., Lei, J., Li, M. X., Wang, X., Hong, Y. J., ... \& Sun, J. (2021). Prevalence and influencing factors of anxiety and depression symptoms among the first-line medical staff in Wuhan mobile cabin hospital during the COVID-19 epidemic: A cross-sectional survey. Medicine, 100(21).

[22] Zhao, Y., Guo, J., Liu, S., Aizezi, M., Zeng, Q., Sidike, A., ... \& Zhang, B. (2021). Prevalence and Related Factors of Depression, Anxiety, Acute Stress, and Insomnia Symptoms Among Medical Staffs Experiencing the Second Wave of COVID-19 Pandemic in Xinjiang, China. Frontiers in Public Health, 9, 489. 